\title{
New Russian Arbitration Law
}

\author{
By Vladimir Orlov* \\ Vladimir Yarkov
}

\begin{abstract}
The updating of the Russian arbitration law following the UNCITRAL Model Law has improved, in particular, the system of domestic arbitration in Russia by offering adequate rules for alternative means of resolution of commercial disputes between enterprises that are alternatives to judicial proceedings; especially significant are the rules strengthening the position of institutional arbitration providing court assistance. Arbitration is to lessen legal intervention in entrepreneurial activities, the necessity of which is still actual in Russia. The new Arbitration Law has, however, reserved some national peculiarities that concern the regulation of domestic arbitration where mandatory rules play an important role.
\end{abstract}

Keywords: Domestic arbitration; International arbitration; Institutional arbitration: Ad hoc arbitration; Arbitration rules; Arbitral Tribunal

\section{General Provisions}

Arbitration proceedings concerning international and domestic entrepreneurial (commercial) disputes as well as institutional and ad hoc arbitration proceedings are recognized in Russia and have recently become subject to changes introduced by the new legislation, including particularly the (Domestic) Arbitration Law of $2015^{1}$ (DA Law), which has entirely replaced the previous law on domestic arbitration (of 2002); it has also amended the regulation related to international commercial arbitration. ${ }^{2}$ Entrepreneurial disputes in Russia are basically subject

* Dr. of Legal Sciences; Professor, Herzen State Pedagogical University of Russia, Saint Petersburg, Russia and Adjunct Professor, University of Helsinki, Helsinki, Finland.

${ }^{\star}$ Dr. of Legal Sciences; Professor, Head of Civil Procedure Department, Ural State University of Law, Yekaterinburg, Russia.

${ }^{1}$ The Law on the Arbitration (Arbitral Proceedings) no 382-FZ of 29 December 2015. The text in Russian is available on the website of Rossiyskaya Gazeta: http://www.rg.ru/2015/12/31/ar bitrazh-dok.html) and on the website of Konsultant Plus: http://www.consultant.ru/document/ cons_doc_LAW_191301 (last accessed April 5, 2017). In English, the law is commented on at http://www.lexisnexis.com/uk/lexispsl/arbitration/document/412012/5J1W-5K01-DYW7-W0

W6-00000-00/New-Russian-arbitration-laws and https://iclg.com/practice-areas/internationalarbitration-/international-arbitration-2016/russia (last accessed April 5, 2017).

${ }^{2}$ Arbitration was known in Russia even in the XIX century. The judicial system of the Russian Empire was familiar with it, since the provisions on arbitration were contained in the Charter of Civil Procedure of 1864. Arbitration procedures were very popular among entrepreneurs in Soviet Russia during the New Economic Policy era (1921-1928). Permanently functioning arbitration institutions - the Foreign Trade Arbitration Commission and the Maritime Arbitration Commission - were established in the early 1930s. In particular, the Foreign Trade Arbitration Commission purported to serve the needs of Russia's foreign trade. Establishment of arbitral tribunals for the settlement of economic disputes between Russian juristic persons was allowed in the Soviet Union from1959. In modern Russia before 2002, domestic 
to the competence of the state commercial courts (arbitrazh courts), the provisions on which are contained in the Arbitrazh Procedural Code of 2002 (as amended in 2017$)^{3}$; the Code has become also subject to changes introduced by the new legislation, in particular by (Article 9 of) the Law on the Amendments to Some Legislative Acts due to the Adoption of the Arbitration Law (Amendment Law of 2015) ${ }^{4}$. Additionally to the DA Law, the Amendment Law has wrought substantial changes to the Law on International Commercial Arbitration of 1993 (ICA Law).

In the Russian reforms of arbitration legislation, the UNCITRAL Model Law on International Commercial Arbitration (as amended in 2006) has been followed in particular ${ }^{5}$. The main purport of the reform performed through the DA Law is to improve domestic arbitration. The new arbitration legislation has also updated international arbitration laws of Russia that apply in cases where the arbitral proceedings are held in Russia (international arbitration seated in Russia) and introduces licensing requirements for foreign arbitration institutions.

The DA Law contains 53 articles and is divided into 12 chapters, in which there are, in addition to the general rules (Ch. 1), including the provisions on the application of the Law and the basic concepts used in the Law, also the rules that apply to the arbitration agreement (Ch. 2), the composition of the arbitral tribunal (Ch. 3) and its jurisdiction (Ch. 4), the conduct of the arbitral proceedings (Ch. 5) as well as the making of awards and termination of proceedings, including the rules concerning settlement (Ch. 6). The Law also includes the rules regulating the recourse against the award (Ch. 7) and the enforcement of this (Ch. 8). Furthermore, the articles of the DA Law contain

arbitration for resolving economic disputes was regulated by the Decree of the Supreme Council of the Russian Federation of 1992, whereas foreign commercial arbitration, meaning, in particular, the International Commercial Arbitration Court (ICAC; the successor of the Foreign Trade Arbitration Commission) and the Maritime Arbitration Commission, is still subject to the provisions of the Law on International Commercial Arbitration of 1993 (as amended in 2008 and 2015). The predecessor of the new law, the Law on Arbitration Courts in Russia of 2002, purported to regulate domestic arbitration in Russia. For more on this subject, see, e.g.: Yarkov (2014), pp. 650-53; Butler (2009) pp. 184-190; Komarov (2001), pp. 87-94; Olshanskaya (2014), pp. 96-102. See also http://lawbook.online/arbitrajnyiy-protsess-rf/kratka ya-istoriya-razvitiya-arbitrajnyih-7719.html; http://jurkom74.ru/materialy-dlia-ucheby/istoriiastanovleniia-arbitrazhnykh-sudov-v-rf; and http://www.tambov.arbitr.ru/about/istorija_sozdani ja (last accessed June 8, 2017).

${ }^{3}$ No 95-FZ of 24 June 2002. The text in Russian is presented on the website of Konsultant Plus: http://www.consultant.ru/document/cons_doc_LAW_37800 and on the website of Garant: http://ba se.garant.ru/71295532/\#ixzz4ggPQp2aR. The Arbitrazh Procedural Code is unofficially translated in English. See http://www.wipo.int/edocs/lexdocs/laws/en/ru/ru072en.pdf (last accessed June 8, 2017).

${ }^{4}$ No 409-FZ of 29 December 2015. The text in Russian is presented on the website of Konsultant Plus: http://www.consultant.ru/document/cons_doc_LAW_191313/b5315c892df70 02ac987a3 $11 \mathrm{~b} 4 \mathrm{a} 242874 \mathrm{fdcf} 420 /$ and on the website of Garant: http://base.garant.ru/71295532/ (last accessed June 8, 2017).

5 Among the peculiarities of the Russian arbitration law is that domestic and international arbitration are clearly differentiated even on the legislative level. The domestic law regulation is characterized by a plenitude of detailed and mandatory rules such as arbitrator qualification requirements and rules on the operation of arbitral institutions. See e.g., https://iclg.com/practi ce-areas/international-arbitration-/international-arbitration-2016/russia (last accessed June 8, 2017). 
the rules on the foundation and activity of permanently functioning arbitral institutions in Russian Federation (Ch. 9), the relation between arbitrazh and mediation proceedings (Ch. 10) and the responsibility of the non-commercial organization at which a permanently functioning arbitral institution is established and of the arbitrator (Ch. 11). In addition, the DA Law contains the final provisions, including the coming-into-force provision. For the significant part, the norms of the DA Law are intended to be dispositive (default rules) (Ch. 12). The ICA Law has content similar to the DA Law, except for details that are presented later.

The DA Law regulates, under the provisions of its Article 1 on its scope of application, the order of foundation and activities of arbitral tribunals and arbitral institutions permanently functioning in Russia as well as the arbitration (arbitral proceedings). The provisions of the law regulating the deposit of arbitral awards, orders of termination of arbitration, and case records (Ch. 39) and the rules on making amendments to legally significant records (Ch. 43) are to be applied not only to domestic arbitration but also, according to Article 1.2 of the ICA Law, to international commercial arbitration seated in Russia ${ }^{6}$. The same concerns the rules on

- the foundation and activity of permanently functioning arbitral institutions in Russian Federation (Ch. 9);

- the relation between arbitration and mediation procedures (Ch. 10) and

- the responsibility of the non-commercial organization at which a permanently functioning arbitral institution is established and of the arbitrator (Ch. 11); as well as the final provisions, including the cominginto-force provision (Ch. 12).

The scope of the DA Law covers disputes between the parties of civil law relations, unless provided otherwise by the federal law (Art. 1.3); the federal law may contain restrictions for submitting certain types of disputes to arbitration (Art. 1.4). In turn, disputes between the parties of civil law relations related to foreign trade and other types of international economic relations may be subject to the application of the ICA Law and submitted to the international commercial arbitration (Art. 1.3).

The main concepts of the DA Law, "arbitration" (арбитраж) and "arbitration proceeding” (третейское разбирательство), are used as synonyms and stand for the procedure of resolution of a dispute by an arbitral tribunal ${ }^{7}$ that may

\footnotetext{
${ }^{6}$ The (Russian) International Commercial Arbitration Court (at the Russian Federation Chamber of Commerce and Industry; ICAC) is subject to the provisions of the Law on International Commercial Arbitration of 1993; the last amendments to the Law on International Commercial Arbitration were brought by the Amendment Law of 2015. On the Russian international commercial arbitration see Karabelnikov (2013).

${ }^{7}$ Arbitration is defined in Article 2 of the DA Law as the procedure of resolution of a dispute by an arbitral tribunal and of decision-making by it (arbitral award).
} 
consist of a sole arbitrator or a panel of arbitrators ${ }^{8}$. In Russian law, the concept of arbitration is, however, problematic, since the term "arbitration", which is translated into Russian as «арбитраж» or «арбитражный суд», is usually related to state arbitrazh courts, and these represent the commercial court system functioning alongside the general court system. Thus, the terms of arbitration and arbitration proceeding will not refer in this article to arbitrazh (or state commercial) court (proceedings) established to solve entrepreneurial (economic) disputes. ${ }^{9}$ Settlement ${ }^{10}$, the rules concerning which are contained in the provisions on termination of arbitral proceedings, and mediation (procedure) ${ }^{11}$, as related to arbitrazh proceedings in the DA Law (Art. 49), are presented in this article as being forms of amicable proceedings (примирительные процедуры) ${ }^{12}$.

\footnotetext{
${ }^{8}$ An arbitrator is, according to Article 2 of the DA Law, a physical person who is chosen by the parties or chosen (appointed) in the order, agreed by the parties or established by the law, for arbitral proceedings. The activities of arbitrators as such are not entrepreneurial activities.

9 The notion of the necessity of special expertise and procedures for settling commercial or economic disputes is as old as the history of the Russian state starting, in particular, from the Moscow period, at the end of which the New Trading Charter of 1667 contained provisions on the custom courts. These courts were followed by commercial courts, the status of which was determined in the Statute of 1832. Commercial courts existed in Russia until the Revolution of 1917. The necessity of the special judicial bodies, instead of administrative procedures, for settlement of economic disputes (between state enterprises and organization) became obvious in the period of the New Economic Policy, and new arbitration commissions were established in 1922. They were, however, terminated and later replaced by the state arbitrazh bodies, which were quasi-judicial bodies founded by the Soviet government and other high executive authorities. At the beginning of the 1990s, the Soviet system of state arbitrazh bodies was, in turn, replaced by the arbitrazh courts (similar to commercial courts). For more on this subject, see, e.g.: Yarkov (2014) at 2014; Butler (2009) at 184-90; Olshanskaya (2014) at 96-102. See also http://lawbook.online/arbitrajnyiy-protsess-rf/kratkaya-istoriya-razvitiya-arbitrajnyih-7719.html http://jurkom74.ru/materialy-dlia-ucheby/istoriia-stanovleniia-arbitrazhnykh-sudov-v-rf, http:// www.tambov.arbitr.ru/about/istorija_sozdanija (last accessed June 8, 2017).

${ }^{10}$ In Russian legal doctrine, settlement (мировоесоглашение) is usually regarded as a specific civil law agreement that is aimed at final resolution of the dispute between the parties, is concluded during the course and within the framework of judicial proceedings, and is subject to judicial enforcement proceedings. See, e.g., Yarkov (2002) at 35-45; Kovalenko, A.G., Mohova A.A., Filippova (2014) at 142; Andreeva (2015) at 556-61; Beltyukova (2016) at 684-86.

${ }^{11}$ Mediation proceedings (процедурамедиации) are, under the law regulating mediation of 2010, a means to settle disputes through the assistance of a mediator on the basis of a voluntary agreement of the parties in order to achieve a satisfactory solution. A mediator is defined, in turn, in the law as an independent physical person who is invited by the parties to assist them as an intermediary in finding the solution based on the merits of the case. As distinguished from mediation, conciliation proceedings (согласительные процедуры), where the conciliator plays a relatively direct role in the actual resolution of a dispute and even advises the parties on certain solutions by making proposals for settlement, are known in the constitutional and criminal law of Russia. See, e.g., http://www.jourclub.ru/33/1800/7/ and http://pandia.ru/text/ 77/339/92263.php (last accessed June 8, 2017).

12 Amicable proceedings (примирительныепроцедуры) represent means of alternative dispute resolution. They are alternatives to judicial proceedings, which are based on voluntary expressions of will of the parties to the dispute and aimed at achieving a solution that is satisfactory to them. Russian civil procedural law and legal doctrine are familiar, particularly, with such means of alternative dispute resolution as negotiation (переговоры), reconciliation (сверка расчетов), mediation (медиация), and judicial settlement (судебное примирение) as well as amicable settlement (мировое соглашение). See, e.g., the Concept of a Single Civil Procedural Code of
} 
The DA Law governs generally, unless otherwise provided by the federal law, both arbitral tribunals administered by a permanent arbitration institution ${ }^{13}$ and ad hoc tribunals founded by the parties to resolve a concrete dispute (Art. 1.5). However, the Law makes a clear distinction between permanent arbitral institutions and ad hoc tribunals, and the foundation and activity of permanently functioning arbitral institutions is subject to special provisions of the DA Law. But the Law also contains the provisions regulating arbitration procedure followed by both arbitral tribunals administered by a permanent arbitration institution and ad hoc tribunals, where differences are also presented.

\section{Organizational Framework for Arbitration}

Russian law recognizes both institutional arbitration, practised by permanent arbitral institutions, and ad hoc arbitration, and makes a clear distinction between them.

Ad hoc arbitration is generally understood as a type of arbitration, the establishment of which is agreed by the parties of the concrete dispute to be resolved. It is not administered by any arbitral institution. Therefore, the parties themselves select the arbitrators and determine the arbitration procedure and this is usually based on the UNCITRAL Arbitration Rules. ${ }^{14}$ Contrary to institutional arbitral tribunals, ad hoc tribunals have no jurisdiction over corporate disputes and may not turn to the state courts to obtain evidence. Moreover, the parties to arbitral proceedings may not, in their arbitration agreement, exclude the right to challenge an arbitrator in the state court, as well as the right to challenge the arbitral award.

In accordance with Article 44 of the DA Law, a permanent arbitral institution is to be established at a non-governmental organization, and its activity is subject to permission obtained by this organization from the Russian Government. However, the International Commercial Arbitration Court (ICAC) and the Maritime Arbitration Commission at the Chamber of Commerce and Industry of the Russian Federation have continued to perform the functions of permanent arbitral institutions in accordance with the recently amended rules without obtaining special permission ${ }^{15}$. The duty to obtain a permit also applies to foreign arbitration institutions ${ }^{16}$.

2014. http://www.consultant.ru/document/cons_doc_LAW_172071/286c4f987b98907587862bc8 99c 9b1c30c11321d/ (last accessed June 8, 2017).

${ }^{13}$ Administration of arbitration is defined in Article 2 of the DA Law as the execution of a permanent arbitration institution of the functions of organizational support to arbitration, including assurance of the procedures of selection, nomination, or challenge of arbitrators, record keeping, arrangement of collection and distribution of arbitration charges, except for the direct dispute settlement functions of the arbitral tribunal.

${ }^{14}$ To assist ad hoc arbitral tribunals in Russia, the Rules of Assistance by the International Commercial Arbitration Court at the Chamber of Commerce and Industry of Russia (ICAC) based on the UNCITRAL Arbitration Rules are applicable. See https://mkas.tpprf.ru/en/predi sk/adhoc/ (last accessed June 8, 2017).

${ }^{15}$ Accordingly, the Chamber of Commerce and Industry has updated the procedural rules of the ICAC and they also concern corporate disputes. See http://mkas.tpprf.ru/ru/ and http://mac. 
To obtain a permit, the arbitral institution is to comply, according to Article 44.8 of the DA Law, with (only) the following requirements: it must

- submit the rules that comply with the DA Law;

- submit a recommended list of arbitrators, which complies with the law;

- ensure that the information provided with respect to the institution and its founders is true, and

- have a reputation of being an organization that will ensure a high level of arbitration activity.

The parties to the dispute that is subject to the arbitral proceedings at the arbitral tribunal established to settle their dispute may agree that the execution of certain functions of arbitral administration, including the appointment and challenging of arbitrators and termination of their mandates, be delegated to the permanently functioning arbitral institution, the rules of which include such activities. The execution of such functions by the arbitral institution does not mean recognizing the arbitral tribunal as being wholly administered by this arbitral institution (Art. 44.19).

The rules of the permanently functioning arbitral institution must contain

- the reference to the DA Law and the ICAC Law as the ground of the activity of the permanently functioning arbitral institution ${ }^{17}$;

- the species of disputes that are administered by the arbitral institution;

- qualifications and other requirements for arbitrators listed by the arbitral institution;

- the organizational structure of the arbitral institution and the order of formation of its bodies as well as the power and functions of its officers participating in the administration of arbitration;

- concrete functions of the arbitral institution that are related to the administration of arbitration, including assistance in composing the arbitral

tpprf.ru/ru/news/pravila-arbitrazha-mak-pri-tpp-rf-i175255/ (last accessed June 8, 2017). The present rules of the ICAC consist of (1) the Regulations on Organizational Principles of Activity of The International Commercial Arbitration Court at The Chamber Of Commerce and Industry of The Russian Federation, (2) the Rules of Arbitration of International Commercial Disputes, and (3) the Rules of Arbitration of Corporate Disputes as well as (4) the Schedule of Arbitration Costs. They have been translated into English. See http://mkas.tpprf.ru/en/docu ments/ (last accessed June 12, 2017).

${ }^{16}$ In order to obtain the permit, foreign arbitral institutions need only be internationally recognized; no other requirements are applicable to them. If a foreign arbitration institution does not obtain the permit, but still conducts arbitral proceedings in Russia, the award of its arbitral tribunal will be deemed to be an award of an ad hoc arbitral tribunal. Thus, a foreign arbitration institution may administer the arbitration seated in Russia, provided that it has obtained the permit of the Russian Government. And in administering corporate disputes, a foreign arbitration institution must publish the special rules for these disputes.

${ }^{17}$ The arbitral institution may have several rules and, also, mixed rules, which are purported for different kind of disputes: international commercial arbitration, domestic arbitration, expedited proceedings, arbitration of certain disputes, arbitration of corporate disputes (art. 45.2). 
tribunal, the handling of challenges, the organization of documentation and the execution of payments;

- the order of the arbitral proceedings corresponding to their rules;

- the differentiation of the competence between the arbitral tribunal and the arbitration institution;

- the applicable standards on impartiality and independence of arbitrators

- the fixed amounts of costs and the rules on determination of costs and their division (Art. 45.4). ${ }^{18}$

In turn, the order of the arbitral proceedings established in accordance with the rules of the permanently functioning arbitral institution must indicate

- the order of filing of a statement of claim and a statement of defence;

- the order of filing of a counterclaim;

- the determination of arbitration costs and their division between the parties;

- the order of presentation, submission, and delivery of documents;

- the order of composition of the arbitral tribunal;

- the grounds and order for solving applications for the challenge of arbitrators;

- the grounds and order for the termination of the arbitrator's mandate and the replacement of arbitrators;

- the term of the proceedings;

- the order of hearings and (or) written proceedings;

- the grounds and order for the suspension or termination of the arbitral proceedings;

- the order and terms for the making, execution and delivery of the arbitral award;

- the order of correction and interpretation of arbitral awards and making of additional awards; and

- the power of the parties and arbitral tribunal with respect to the determination of the order of the arbitral proceedings and the issues in respect of which the deviations from the arbitration procedure or the specification of them by conclusion of the agreement of the parties and (or) by issuance of a procedural order by the arbitral court (Art. 45.5).

The rules of the permanently functioning arbitral institution may include, in addition to those mentioned above, other provisions that are not contradictory or inconsistent with the law. But the provisions that must be agreed only directly between the parties under the DA Law, may not be contained, according to Article 7.12 of the DA Law, in the rules of the permanently functioning arbitral institution. Furthermore, the order of the arbitral proceedings may provide that, by their agreement, the parties are not entitled to make any changes to the rules

\footnotetext{
${ }^{18}$ Permanent arbitral institutions are responsible only for organizational support. They have no powers to resolve disputes.
} 
of the arbitral proceedings except for the provisions that may be, in accordance with the DA Law, directly agreed by the parties (Art. 45.6).

According to Article 45.9 of the DA Law, the provisions of the rules of the permanently functioning arbitral institution that are contradictory with the law are regarded null and void, and this may be the ground for revocation (setting aside) of or refusal to enforce the arbitral award.

The activity of a permanently functioning arbitral institution may be terminated under Article 48 of the DA Law by the decision of the noncommercial organization at which a permanently functioning arbitral institution is established or of the arbitrazh court in cases where numerous serious violations of the law have resulted in damage to the parties or third parties and orders to cease violations have not been complied with. Such a termination is not considered as grounds for revocation of or refusal to enforce an arbitral award.

\section{Interference of State Courts with Arbitral Proceedings}

As an exception to the general prohibition of any judicial interference in arbitral activities expressed in Article 5 of the DA Law (and also of the ICA Law), this Law also provides the rules that allow the courts to assist in the arbitration procedure. According to the default provisions of the DA Law, the state courts in Russia may assist arbitral tribunals by appointing (Art. 11) and challenging an arbitrator (Art. 13.3) and terminating the mandate of an arbitrator (Art. 14.1).

With respect to arbitral tribunals administered by a permanent arbitration institution, the parties of arbitration agreement may, however, exclude these issues from consideration of the court.

The state court may also assist arbitration by

- granting interim measures (Art. 17),

- determining lack of jurisdiction of the arbitral tribunal (Art. 16.3),

- obtaining evidence (except for ad hoc arbitration) (Art. 30), and

- terminating the activity of an arbitral institution (Art. 48.4).

\section{Arbitrability of Disputes}

According to Article 1.3 of the DA Law, the parties to civil law relations may, under their agreement, submit their dispute to arbitration (arbitral proceedings), unless otherwise provided by the law.

The main rules on arbitrability of domestic disputes are contained in Articles $27^{19}$ and $33^{20}$ of the Arbitrazh Procedure Code. In accordance with these articles, any domestic civil law dispute that is related to economic activities is

\footnotetext{
${ }^{19}$ Where the jurisdiction of arbitrazh (state commercial) courts is determined.

${ }^{20}$ Which allows certain disputes under the jurisdiction of arbitrazh courts to be submitted to arbitration procedure.
} 
arbitrable by domestic arbitration, unless otherwise provided by a federal law. Non-arbitrable disputes are, under the Arbitrazh Procedure Code, insolvency (bankruptcy) disputes, disputes on avoidance or refusal in state registration of juristic persons, and on other public law related matters, including privatization, as well as certain intellectual property and corporate disputes; corporate disputes are subject to special rules of the Arbitrazh Procedure Code and DA Law, which are presented later.

International commercial disputes are, in turn, subject to the provisions of the legislation on international commercial arbitration in Russia ${ }^{21}$. In accordance with the provisions of Article 1.3 of the ICA Law ${ }^{22}$, disputes that could be submitted to the international commercial arbitration court are the civil law disputes arising in connection with foreign trade and other international economic relations between parties if:

- the place of business of one of the parties is located outside Russia; or

- the place where a substantial part of the obligations is to be performed is located abroad or

- the place where the subject matter of the dispute is most closely connected with a foreign state.

In addition, disputes related to international investments in Russia or Russian investments abroad are under the jurisdiction of the international commercial arbitration court ${ }^{23} \cdot{ }^{24}$

\section{Corporate Disputes}

Corporate disputes are defined, in accordance with Article 2.11 of the DA Law, as disputes related to the foundation of a juristic person in Russia, its management or participation therein, the parties of which are the founders and participants of the juristic person (the participants) and the juristic person itself, including disputes connected with the legal relation established between the juristic person and a third party that are initiated by the participants in the event that the federal law ${ }^{25}$ allows this.

Corporate disputes are subject to special rules of the DA Law (Art. 45) and the Arbitrazh Procedure Code ${ }^{26}$, according to which they, if not excluded ${ }^{27}$, are

\footnotetext{
${ }^{21}$ Based on the Law on International Commercial Arbitration (ICA Law) of 1993 (as amended in 2008 and 2015). See, e.g.: http://base.garant.ru/10101354/(last accessed June 8, 2017).

${ }^{22}$ See also $\S 1$ of the Rules of the Court of International Commercial Arbitration of 2017. https: //mkas.tpprf.ru/ru/(last accessed June 8, 2017).

${ }^{23}$ Furthermore, Article 1.4 of the ICA Law provides that, if a party has more than one place of business, the place of business is that which is of most relevance to the arbitration agreement. But if a party does not have a place of business, reference is to be made to his permanent residence.

${ }^{24}$ These provisions are different from the UNCITRAL Model Law.

${ }^{25}$ Arbitrazh Procedural Code, art. $225^{1}$.

${ }^{26}$ Arbitrazh Procedural Code, art. $225^{1}$.
} 
exclusively to be arbitrated by arbitral tribunals administered by a permanent arbitration institution that follows the approved rules of arbitration on corporate disputes. Corporate disputes that are subject to such exclusive jurisdiction concern the foundation of a juristic person in Russia, as well as its governance and participation in it. They also include disputes connected with the legal relation established between the juristic person and a third party, provided that the parties are entitled under the law to initiate the proceedings. ${ }^{28}$ In default of the approved rules of arbitration on corporate disputes, an arbitral tribunal administered by a permanent arbitration institution may settle disputes regarding the holding of shares and participating interests and the creation of encumbrance over and the exercise of rights arising from these (including disputes arising from share sale and purchase agreements) as well as disputes that are related to the activities of share registrars. Corporate disputes may also be settled in the (Russian) International Commercial Arbitration Court in accordance with the Rules on Arbitration of Corporate Disputes enacted by the Russian Chamber of Commerce and Industry in $2017^{29}$.

According to Article 45.8 of the DA Law, the rules of arbitration on corporate disputes must contain:

- the duty of the permanently functioning arbitration institution to inform the juristic person, against which the dispute has arisen, about the submitted claim and submit a copy of this to him and to place on its website the information about the submitted claim within 3 days of receiving the statement of claim;

\footnotetext{
${ }^{27}$ Excluded under Article $225^{1} .2$ of the Arbitrazh Procedural Code are the disputes that concern (a) the convening of general shareholders' meetings, (b) the activities of notaries on certification of transactions with participation interests in limited liability companies, (c) the strategic companies, except for disputes arising from the transactions on interests in such companies, which are not subject to governmental approval, (d) certain cases of buyback and compulsory buyout of shares by a company, voluntary, mandatory, and competitive tender offers and buyout of shares by shareholders, and (e) the expulsion of a participant from a juristic person, as well as the disputes related to the challenging of non-normative legal acts, decisions and actions (inactions) of state and municipal bodies and other public authorities. See, e.g., https://www.morganlewis.com/ /me $\mathrm{dia} /$ files/document/chart-1-type-of-corporate-dispute.ashx?la=en

${ }^{28}$ Additionally, certain disputes require that all the participants of a juristic person and other parties to the dispute have concluded an arbitration agreement. These are the disputes concerning (a) the establishment, reorganization and liquidation of a juristic person, (b) claims of shareholders for recovery of damages caused to a juristic person and/or for application of the consequences of invalidity of such transactions; (c) the appointment/election and removal of the governing bodies of a juristic person and their liabilities and the agreements between participants concerning management of the juristic person, including corporate agreements, (d) the issuance of securities and (e) the challenging of decisions of the governing bodies of the juristic person (art. 225 $5^{1} .2$ ).

${ }^{29}$ A dispute that is subjected to the application of the ICAC Corporate Dispute Rules may relate to: (a) the establishment, reorganization and liquidation of a juristic person, (b) claims of shareholders for recovery of damages caused to a juristic person and/or for application of the consequences of invalidity of such transactions, (c) agreements regarding corporate governance, (d) the issuance of securities, (e) the challenging of decisions of the governing bodies of the juristic person, and (f) the disclosure of information to shareholders.
} 
- the duty of the juristic person to inform its participants about the submitted claim;

- the right of each participant of the juristic person to join the (further) proceedings at any stage by submitting his written application to the tribunal; and

- the duty of the arbitration institution to inform all the participants of the juristic person, who have joined the proceedings, about the further course of the proceedings.

The rules of arbitration on corporate disputes must also provide that

- the withdrawal from claim, the recognition of the withdrawal, and the conclusion of the settlement are allowed without the consent of all the participant of the juristic person, who have joined the proceedings, except for the case when a participant submits his objection against that, and the tribunal states that the participant has legal interest for the continuation of the proceedings.

\section{Arbitration Agreement}

An arbitration agreement comprehends, according to Article 7 of the DA Law (and also of the ICA Law), an agreement by the parties to submit to arbitration all or certain disputes which have arisen or which may arise between them with respect to a concrete legal relationship, whether contractual or not ${ }^{30}$.

An arbitration agreement is to be in writing (contained in a document signed by the parties) and may be concluded in the form of an arbitration clause in a contract $^{31}$ or in the form of a separate agreement ${ }^{32}$. An arbitration agreement is considered concluded also in an exchange of statements of claim and defence in which the existence of an agreement is alleged by one party and not denied by another. Moreover, the reference in a contract to a document containing an arbitration clause is regarded as an arbitration agreement in writing, provided that the reference is to be regarded as a part of the contract. ${ }^{33}$ An arbitration agreement concerning corporate disputes (exclusively arbitrable by arbitral tribunals administered by a permanent arbitration institution)could be included

\footnotetext{
${ }^{30}$ According to Article 38 of the DA Law, the parties who have concluded the arbitration agreement are under the obligation to fulfill the arbitral award voluntarily.

${ }^{31}$ An arbitration clause that is included in the contract concerns any disputes related to conclusion of the contract and its entry into force and termination as well as its validity, including subsequent restoration, unless otherwise is agreed. This rule is different to the UNCITRAL Model Law.

${ }^{32}$ An agreement is also regarded as concluded in writing if it occurs by the exchange of documents by mail, telegraph, teletype, telephone, electronic, or other communications enabling reliable determination of the fact that the document comes from the other party.

33 An arbitration agreement could be contained in rules on the organization of auctions and clearings.
} 
into the charter of a juristic person ${ }^{34}$ (excluding the cases of joint-stock companies with more than 1000 shareholders and public companies).

An arbitration agreement is by nature an independent agreement, and this also concerns arbitration clauses. Thus, invalidity of the contract does not mean the invalidity of the arbitration clause; moreover, any doubts as to the validity of an arbitration clause are to be interpreted in favour of its validity and enforceability. Furthermore, the arbitration rules that are referred to in the arbitration agreement are regarded, according to Article 7.12 of the DA Law, as an inseparable of these agreements.

\section{Composition of Arbitral Tribunal}

The number of arbitrators is determined, according to Article 10 of the DA Law (and also of the ICA Law), by the parties of arbitration, provided that the number is odd. In default of their agreement, the number of arbitrators ought to be three. According to the Article 11 of DA Law (and also the ICA Law), the parties may, in principle, determine the appointment procedure. Failing such agreement, the arbitral tribunal is to be composed as follows:

- in an arbitration with three arbitrators, each party appoints one arbitrator, and these two arbitrators are to determine the third arbitrator and

- in an arbitration with a sole arbitrator, if the parties are unable to agree on the arbitrator, he is to be appointed, upon request of a party, by the competent $\operatorname{court}^{35}$.

The court is otherwise empowered, upon request of a party, to take the necessary measures, unless the agreement on the appointment procedure provides other means, for securing the appointment. However, with respect to arbitral tribunals administered by a permanent arbitration institution, the parties of the arbitration agreement may exclude the court from taking any measures related to the appointment of arbitrators.

According to the DA Law (Art. 11), the arbitrator(s) must correspond with the requirements provided by the law as well as any additional requirements possibly agreed by the parties, which are purported to secure the appointment of an independent and impartial arbitrator(s). In accordance with the DA Law (Art.12), the (candidate and the appointed) arbitrator must disclose to the parties and the tribunal without delay any circumstances that render his/her impartiality or independence doubtful.

According to the DA Law (Art. 12), an arbitrator may be challenged, however, only if circumstances that give rise to justifiable doubts in respect of

\footnotetext{
${ }^{34}$ This is different from the UNCITRAL Model Law.

${ }^{35}$ The references to a competent court in the DA Law generally stand for the references to the arbitrazh court in which jurisdiction the case would lie otherwise (if not handled in the arbitral proceedings).
} 
his/her impartiality or independence exist, or if he/she does not possess qualifications required by the law or agreed to by the parties. A party may challenge an arbitrator appointed by him, or in whose appointment he has participated, only for reasons of which he becomes aware after the appointment has been made.

The parties may agree, under the DA Law (Art.13) on the procedure for challenging an arbitrator. Failing such agreement, a party who intends to challenge an arbitrator must, within fifteen days after becoming aware of the constitution of the arbitral tribunal or after becoming aware of any obstacle preventing the arbitrator from serving as such, send a written statement of the reasons for the challenge to the arbitral tribunal. Unless the challenged arbitrator withdraws from his/her office or the other party agrees to the challenge, the arbitral tribunal must decide on the challenge. In the event of an unsatisfactory decision by the tribunal, the issue becomes subject to court proceedings. However, with respect to arbitral tribunals administered by a permanent arbitration institution, the parties of arbitration agreement may exclude from the court the power to decide on the challenge of arbitrators.

\section{Jurisdiction of the Arbitral Tribunal}

The arbitral tribunal may rule, according to Article 16 of the DA Law (and also of the ICA Law), on its own jurisdiction, and it includes any objections with respect to the existence or validity of the arbitration agreement. Therefore, an arbitration clause that forms part of a contract ought to be treated as an agreement independent of the other terms of the contract. Thus, a decision of the arbitral tribunal that the contract is invalid is not to entail ipso jure the invalidity of the arbitration clause.

A plea that the arbitral tribunal does not have jurisdiction must be presented by the party in question not later than when he/she submits his/her first statement of defence. In turn, a plea that the arbitral tribunal is exceeding the scope of its authority must be raised as soon as this question is raised during the arbitral proceedings $\mathrm{s}^{36}$. In either case, a later plea is admissible in the event that the delay is justified. A preliminary decision of the arbitral tribunal on its jurisdiction may be appealed to the court. However, with respect to arbitral tribunals administered by a permanent arbitration institution, the parties of arbitration agreement may exclude the right to such an appeal.

The DA Law also contains default provisions on the power of the arbitral tribunal to order interim measures. According to its Article 17 (and also of the ICA Law), the arbitral tribunal may, unless otherwise agreed by the parties,

\footnotetext{
${ }^{36}$ Furthermore, the rules on waiver of right to object of Article 4 of the DA Law (and also of the ICA Law) provide that, if a party who knows that any dispositive provision of the law or any requirement under the arbitration agreement has not been complied with and yet proceeds with the arbitration without stating his/her objection to such non-compliance without undue delay or, if a time-limit is provided there for, within such period of time, is to be deemed to have waived his/her right to object.
} 
order a party to take any interim measure of protection that the arbitral tribunal considers necessary in the case at hand; it may also require (a party requesting an interim measure) to provide appropriate security in connection with such measures. Interim measures may be also granted by an arbitration institution (before formation of the arbitral tribunal) or even by a competent state court (Art. 9).

\section{Conduct of Arbitral Proceedings}

Arbitral tribunal is to be conducted, under Article 18 of the DA Law, on the principles of independence and impartiality of arbitrators and dispositiveness as well as competition and equal treatment of parties. Subject to the mandatory provisions of the Law, the parties may agree, in accordance with Article 19 of the DA Law, on the procedure to be followed by the arbitral tribunal. In default of such an agreement, the arbitral tribunal may, unless otherwise provided for by the DA Law, conduct the arbitration in such manner as it considers appropriate, including its power to determine the admissibility, relevance, and significance of any evidence.

The default provisions of the DA Law on conducting arbitral proceedings include, furthermore, the rules ${ }^{37}$ on the place (Art. 20) and language (Art. 24) of arbitration, confidentiality (Art. 21) and commencement of arbitral proceedings (Art. 23), statements of claim and defence (Art. 25) and arbitration costs (Art.22), presentation of evidence (Art. 26) and hearings and written proceedings (Art. 27) as well as failure of a party to present documents or to appear (Art. 28) and expert appointed by arbitral tribunal (Art. 29) and finally the rules on court assistance in taking evidence (Art. 30) applicable to proceeding of permanent arbitration institutions. Similar rules are contained in Articles 18-27 of the ICA Law.

According to the provisions of the DA Law on commencement of arbitral proceedings (Art. 23), the arbitration with respect to a particular dispute is regarded as commenced, unless otherwise agreed by the parties, on the date on which the statement of claim is received by the respondent. Unless otherwise agreed by the parties, the claimant submits his/her demands in the statement of claim in written form to the respondent and (if applicable) to the permanently functioning arbitral institution (Art. 25.1). Unless otherwise agreed by the parties, the statement of claim must indicate, among others:

- the demands of the claimant;

- the facts on which his claim is based, and

- the evidence supporting the grounds for the claim (Art. 25.2).

In turn, the respondent is entitled to submit to the claimant and (if applicable) to the arbitral tribunal

${ }^{37}$ Following, without substantial exceptions, the UNCITRAL Model Law on International Commercial Arbitration. 
- their defence to the statement of claim with his/her objections to the claim (Art. 25.4).

- Unless the term for submission of the defence is determined by the arbitration rules or by the arbitral tribunal, the defence must be submitted before the first hearing of the arbitral tribunal (Art. 25.5).

Unless otherwise agreed by the parties, a party is entitled to amend or supplement his/her claim or defence as well as submit additional evidence during the course of the arbitral proceedings, unless the arbitral tribunal refuses to take the amended claim or defence or additional evidence having regard to the delay in presenting them (Art. 25.6).

According to the provisions on presentation of evidence of the DA Law (Art. 26), each party is obliged to prove the circumstances to which he/she refers as a ground for his/her demands and objections. If the evidence is regarded as insufficient, the arbitral court may demand additional evidence. With respect to arbitral tribunals administered by a permanent arbitration institution, the arbitral tribunal or a party with the approval of the arbitral tribunal may, as mentioned above, request from a competent state court assistance in taking evidence (Art. 30). Subject to any contrary agreement by the parties, the arbitral tribunal decides, according to Article 27 of the DA Law, whether to hold oral hearings for the presentation of evidence or for oral argument, or whether the proceedings ought to be conducted on the basis of documents and other materials. However, the arbitral tribunal must hold hearings at an appropriate stage of the proceedings at the request of a party, unless the parties have expressly agreed not to hold hearings. Unless otherwise agreed by the parties, the default of a party in the arbitral proceedings does not prevent, under Article 28 of the of the DA Law, the continuation of the proceedings, whereas the failure of the respondent to submit his/her statement of defence is not to be considered as an admission of the claim.

\section{Making of Award and Termination of Proceedings}

In making of award, under the rules applicable to substance of dispute of the DA Law (Art. 31) and also of the ICA Law (art. 28), the arbitral tribunal decides the dispute in accordance with the norms of Russian law. But if the parties may choose, in accordance with the Russian law, a foreign law to be applicable to their relations, the dispute is to be decided in accordance with such rules of law as are chosen by the parties as applicable to the substance of the dispute. Failing such a designation, the arbitral tribunal applies the law determined by the conflict of laws rules which it considers applicable. Besides, any designation of the law or legal system of a given State must be construed as referring directly to the substantive law of that State and not to its conflict of laws rules. Moreover, the arbitral tribunal makes its decisions in accordance with the terms of the contract, taking into account the customs to be applied. 
An arbitral award is to be made, according to Article 32 of the DA Law (and also Article 29 of the ICA Law), by the arbitral tribunal after considering the circumstances of the case. In arbitral proceedings that are executed by the panel of arbitrators any decision of the arbitral tribunal must be made, unless otherwise agreed by the parties, by a majority of the arbitrators. However, questions of procedure may be decided by a presiding arbitrator, if so authorized by the parties or all other arbitrators.

The arbitral award is to be made, according to Article 34 of the DA Law (and also Article 31 of the ICA Law), in writing and must be signed by the arbitrator or arbitrators, including the arbitrator who has the dissenting opinion; the dissenting opinion must be attached to the award. In arbitral proceedings that are executed by the panel of arbitrators, the signatures of the majority of all members of the arbitral tribunal is to suffice, provided that the reasons for omitted signatures are stated. The arbitral award is to indicate, unless otherwise agreed by the parties:

- the place where and the day on which it is made;

- the composition of the arbitral tribunal and the order of its formation;

- the names and sites of the parties of the arbitral proceedings;

- the grounds for the jurisdiction of the arbitral tribunal;

- the claim and the defence as well as the requests of the parties;

- the circumstances of the case established by the arbitral tribunal, the evidence on which the conclusion of the arbitral tribunal about these circumstances are based as well the legal norms on which the arbitral tribunal relied in adopting its decision. The arbitral award is also to include

- the resume part that contains the conclusions of the arbitral tribunal on the approval or rejection of each of the presented claim. ${ }^{38}$ Also according to Article 31 of the ICA Law, the award must state (among other requirements) the reasons upon which it is based and contain conclusions on granting or dismissing the claims ${ }^{39}$.

The arbitral proceedings are terminated, in accordance with Article 36 of the DA Law (and also Article 32 of the ICA Law), by the award of the arbitral tribunal or by its order for the termination of the arbitral proceedings in the event that:

\footnotetext{
${ }^{38}$ The resume part of the arbitral award includes the ruling on the arbitration fees and costs, and, if necessary, may contain the provisions on the execution of the arbitral award.

${ }^{39}$ Additionally, the corporate dispute decision of the ICAC must, according to the Rules on Arbitration of Corporate Disputes, (a) indicate the names of all interested parties known to the arbitral court (to have an interest in the case) and (b) state that the company is properly informed about the filed claim and (c) this information is disclosed on the website of the ICAC as well as that (9) the company has duly informed interested persons and the share registrar about the commenced proceedings. The same requirements also concern the order for the termination of the proceeding.
} 
- the claimant withdraws his claim, unless the respondent presents his/her objections against the termination of the arbitration and the arbitral tribunal recognizes his/her legitimate interest in obtaining a final settlement of the dispute;

- the parties agree on the termination of the arbitration;

- the arbitral tribunal finds that the continuation of the proceedings has for any other reason become unnecessary or impossible, including the case when there exists a decision of a court of general jurisdiction, of an arbitrazh court or of an arbitral tribunal, adopted on the dispute between the same persons, on the same object and on the same grounds.

The norms of the DA Law regulating the making of award and termination of proceedings (Ch. 6) contain, furthermore, provisions on correction and interpretation of award, additional award, and resumption of arbitral proceedings (Art. 37). Similar provisions are contained in Article 33 of the ICA Law.

According to the provisions on correction and interpretation of award of the DA Law (and also of the ICA Law), a party, with notice to the other party, may request the arbitral tribunal to correct in the award any errors in computation, any clerical or typographical errors or any errors of a similar nature. However, such a request ought to be presented within thirty days of receipt of the award, unless another period of time has been agreed upon by the parties. Furthermore, if so agreed by the parties, a party, with notice to the other party, may request the arbitral tribunal to give an interpretation of any point or part of the award. If the arbitral tribunal considers the request to be justified, it must, within thirty days of receipt of the request, make the correction ${ }^{40}$ or give the interpretation, and they form part of the award.

Also an additional award can be made by the arbitral tribunal, unless otherwise agreed by the parties, on request of a party, with notice to the other party within thirty days of receipt of the award. Such an award may concern claims presented in the arbitral proceedings but omitted from the award. If the arbitral tribunal considers the request to be justified, it must make the additional award within sixty days (Art. 37.4 of the DA Law and also Art. 33.3 of the ICA Law).

According to the provisions on resumption of arbitral proceedings, which are contained in Article 37.6 of the DA Law (and Article 33.4 of the ICA Law), in the event that a competent state court, considering the application for cancellation or execution of the arbitral award, suspends the proceedings in order to give the arbitral tribunal an opportunity to resume the arbitral proceedings and eliminate the grounds for cancellation or refusal of compulsory execution of the arbitral award, the arbitral tribunal may, upon request of any party, resume the proceedings.

\footnotetext{
${ }^{40}$ The arbitral tribunal may also, on its own initiative, make the correction within thirty days of the date of the award (art. 37.3).
} 


\section{Amicable Proceedings}

Amicable proceedings fall, to some extent, under the scope of the DA Law. This contains the rules concerning settlement as well as the rules related to mediation. The rules regulating settlement are also included in the ICA Law.

Settlement is subject to the provisions of the DA Law in its Article 33 (and also Article 30 of the ICA Law). According to this, if, during the arbitral proceedings, the parties resolve the dispute, the arbitral tribunal terminates the proceedings and, upon request of the parties and in default of its own objections, records the settlement in the form of an arbitral award on agreed terms. Such an award must correspond to the general requirements on making of arbitral awards, which concern the rules applicable to substance of dispute in Article 31 of the DA Law presented above. The dispute ought to be decided in accordance with Russian law, including, if necessary, international private law norms, and also in accordance with the terms of the contract taking into account the customs to be applied. The arbitral award based on settlement must contain the statement of being the arbitral award that has the same status and force as any other arbitral award on the merits of the case.

According to the rules on application of mediation proceedings to a dispute subjected to arbitrazh proceedings, provided in Article 49 of the DA Law, the application of mediation proceedings is allowed at any stage of the arbitral proceedings.

In the event that the parties have decided to turn to mediation proceedings, any of them is entitled to submit to the arbitral tribunal the application for mediation attached with the agreement to mediate concluded in written form and corresponding to the requirement provided for by the Law on Alternative Proceedings of Dispute Resolution with Participation of a Mediator (Mediation Proceedings) of $2010^{41}$ (Art.49.2). According to Article 8 of this law, the agreement must indicate

- the subject of the dispute,

- the mediator(s) or the organization providing mediation services,

- the mediation procedure,

- the cost-sharing between the parties, and

- the term of the execution of the proceedings.

On the basis of the submitted application, the arbitral tribunal issues the order for mediation (Art 49.3). During the term of the mediation proceedings, the arbitral proceedings of the dispute are suspended (Art. 49.4).

The mediation agreement, concluded (in writing) by the parties as the result of the mediation proceedings after the dispute has been submitted to arbitration, could be enforced by the arbitral tribunal upon the request of all the

\footnotetext{
${ }^{41}$ No 193-FZ of 24 July 2010. The text in Russian is presented on the website of Konsultant Plus: http://www.consultant.ru/document/cons_doc_LAW_103038/560ab66036fc78930e9138dff12b c502fe21fd (last accessed June 13, 2017).
} 
parties as an arbitral award on agreed terms, provided that the above-presented requirement concerning settlement (Art. 33) has been followed.

\section{Recourse against the Award}

According to Article 230 of the Arbitrazh Procedural Code (amended in 2017), an arbitral award can be challenged, by the parties to the proceedings and also by the persons, the rights and duties of whom are subject to the award, as well as by the procurator in defence of rights of the state or a municipal body that have not participated in the proceedings.

According to the provisions of Article 34 of the ICA Law, recourse to a court against an arbitral award may be made only by an application for setting it aside provided that the applicant furnishes proof that:

- a party to the arbitration agreement was under some incapacity; or

- the said agreement is not valid under the law to which the parties have subjected it or, failing any indication thereon, under Russian law; or

- the applicant was not properly informed about the appointment of an arbitrator or of the arbitral proceedings, including of the time and place of the hearing, or was for other valid reasons unable to present his/her case; or

- the arbitral award concerns a dispute not contemplated by or not falling within the terms of the arbitration agreement, or contains decisions on issues beyond the scope of the arbitration agreement ${ }^{42}$; or

- the composition of the arbitral tribunal or the arbitral procedure was not in accordance with the agreement of the parties or the law.

The arbitral award may also be revoked (set aside) by the competent court if it finds that:

- the subject-matter of the dispute might not be settled by arbitration in accordance with the law; or

- the award is in conflict with the public policy of Russia. ${ }^{43}$

Where the arbitration is administered by a permanent arbitral institution, the parties may, however, in the arbitration agreement, directly agree, according to Article 40 of DA Law (and also Article 34.1 of the ICA Law), that the arbitral

\footnotetext{
${ }^{42}$ If the decisions on issues subjected to the arbitration agreement can be separated from those not subjected, that part of the award which contains decisions on issues not subjected to the agreement may be revoked.

${ }^{43}$ Under Article 34.3 of the ICA Law, an application for revoking the arbitral award may not be submitted after expiry of the term of three months from the day the applicant had received the award or, in the event of correction and interpretation of award and additional award, from the day of the decision on the request for it.
} 
award is final ${ }^{44}$, and such a final decision is irrevocable. In the event that the arbitration agreement does not contain any such provision, the arbitral award may be revoked on the grounds established by the procedural legislation of Russia.

\section{Enforcement of Awards ${ }^{45}$}

An arbitral award is, under Article 41 of the DA Law (and also Article 35 of the ICA Law), to be recognized as binding and subject to immediate enforcement, unless otherwise provided for. ${ }^{46}$ Upon application of the party, made in writing, the competent court issues the writ of execution by which the arbitral award made in Russia is to be executed in accordance with the DA Law and provisions of the procedural legislation of Russia ${ }^{47}$. ${ }^{48}$

According to Article 42 of the DA Law, enforcement of an arbitral award by issuing the writ may be refused only on the grounds established by procedural law ${ }^{49}$. With respect to the ICAC decisions, the recognition or enforcement of an arbitral award, irrespective of the country in which it was made, may be refused, according to Article 36 of the ICA Law ${ }^{50}$, at the request of the party against whom the award is invoked or on the initiative of the competent court.

The recognition or enforcement of the arbitral award may be refused at the request of the party against whom it is invoked, if that party furnishes to the competent court where recognition or enforcement is sought proof that:

- the award was issued based on the arbitration agreement (concerning the dispute) and one of the parties thereto was under some incapacity; or

\footnotetext{
${ }^{44}$ This is different from the UNCITRAL Model Law.

${ }^{45}$ For more on the subject see Yarkov (2017).

${ }^{46}$ According to the principle of binding force of an arbitral award established in Article 38 of the DA Law, the parties who have concluded the arbitration agreement are under obligation to voluntarily fulfil the arbitral award. Moreover, the parties and the arbitral tribunal have to take all reasonable effort in order that the arbitral award is legally executable. In particular, the binding force of the arbitral award means that its conclusions are final concerning (a) the circumstances of the case established by the arbitral tribunal, (b) the relevance, admissibility, credibility, and sufficiency of the evidences, and (c) the legal relations between the parties (res judicata). See Yarkov (2017).

${ }^{47}$ E.g. Articles $236-40$ of the Arbitrazh Procedure Code, and, in the event of an international commercial arbitration seated in Russia, also Articles 35 and 36 of the ICA Law are to be applied.

${ }^{48}$ With respect to purely foreign arbitral awards, their enforcement in Russia is subject to the provisions of the New York Convention (on the Recognition and Enforcement of Foreign Arbitral Awards; New York, 1958), Articles 35 and 36 of the ICA Law, and Articles 241-46 of the Arbitrazh Procedure Code.

${ }^{49}$ The general prohibition of any judicial interference in arbitral activities expressed in Article 5 of the DA Law (and of the ICA Law) concerns especially the enforcement of arbitral awards. In particular a foreign arbitral award may not be subject to new (judicial) proceedings. In enforcing the award, only the documents listed in the Arbitrazh Procedure Code are to be submitted to the competent court, and they include the copy of the award, the arbitration agreement and the notification to the other party about the enforcement application.

${ }^{50}$ These rules are similar to the rules provided in Article 239 of the Arbitrazh Procedural Code, which concern the grounds for refusal to issue the writ of execution.
} 
- the arbitration agreement is not valid under the law to which the parties have subjected it or, failing any indication thereon, under the law of the country where the award was made; or

- the party against whom the award is made was not properly informed about the appointment of an arbitrator or of the arbitral proceedings, including of the time and place of the hearing or was for other valid reasons unable to present his/her case; or

- the award concerns a dispute not contemplated by or not falling within the terms of the arbitration agreement, or it contains decisions on matters beyond the scope of the arbitration agreement ${ }^{51}$; or

- the composition of the arbitral tribunal or the arbitral procedure was not in accordance with the agreement of the parties or the law of the country where the arbitration took place; or

- the award made in a foreign state has not yet become binding on the parties or has been set aside (revoked) or suspended by a competent authority of the country in which it was made, or of the country, the law of which is to be applied.

The recognition or enforcement of the arbitral award may be refused on the initiative of the competent court, if it finds that:

- the subject-matter of the dispute might not be settled by arbitration in accordance with federal law; or

- the recognition or enforcement of the award is in conflict with the public policy of Russia.

According to Article 36.3 of the ICA Law, the enforcement of an arbitration decision via issuing a writ of execution may be refused on the initiative of the competent court even in the event that the party against which the award was made does not refer to the specified grounds. ${ }^{52}$

\section{Liability Rules}

An arbitral institution is liable, according to Article 50 of the DA Law, only for damages caused by intentional or grossly negligent breach of its duties; the rules of the institution may provide, however, greater liability. An arbitral institution is not liable for actions of the arbitrator. In turn, an arbitrator is

\footnotetext{
${ }^{51}$ If the decisions on issues subjected to the arbitration agreement can be separated from those not subjected, that part of the award which contains decisions on issues subjected to the agreement may be recognized and enforced.

52 The ICA Law also contains the rule concerning a foreign arbitral award that does not require enforcement. The party against which such an award was issued is entitled to present his/her objections against its recognition in accordance with Russian law (art.35.5).
} 
immune from civil liability; however, he is not protected from a civil claim in a criminal proceeding. ${ }^{53}$

\section{Conclusions}

The new Russian arbitration law, together with the Amendment Law, has improved, following the UNCITRAL Model Law amended in 2006, the system of regulation of arbitration and particularly of domestic arbitration in Russia. Especially significant are the rules strengthening the position of institutional arbitration providing, if necessary, court interference in arbitral proceedings. Now Russian law offers, with respect not only to international but also domestic arbitration, adequate rules for means of resolution of commercial disputes between enterprises that are alternatives to judicial proceedings. Thus, in Russia as well, arbitration is becoming a means to lessen legal intervention in the entrepreneurial activities, the necessity of which is still actual in the country.

Incidentally, the new Russian Arbitration Law has, however, reserved some national peculiarities that concern the regulation of domestic arbitration where mandatory rules play an important role. It reflects the Russian legal tradition with its belief in the efficiency of legislative means.

\section{References}

Andreeva, E.V. (2015). 'Правовая природа мирового соглашения в гражданском судо производстве' [Legal Nature of Settlement in Civil Procedure]. Молодой ученый [Young Scholar]. 21: 556-561.

Beltyukova, I.M. (2016). 'Проблемные вопросы заключения мирового соглашения по экономическим спорам, вытекающим из административных и иных публичных правоотношений' [Problematic Issues of Conclusion of Settlement Related to Economic Disputes Arising in Administrative and Other Public Law Relations]. Молодой ученьій [Young Scholar]. 3: 684-686.

Butler, W.E. (2009). Russian Law. Oxford University Press.

Karabelnikov, B.P. (2013). 'Международный коммерческий арбитраж' [International Commercial Arbitration]. Moscow. Freely accessible on http://arbitrations.ru/us erfiles/file/Publications/Publications/Karabelnikov\%20Mezhdunarodny\%20arbitr azh.pdf (last accessed June 8, 2017).

Komarov, A.S. (2001). 'Основополагающие принципы третейского суда' [Fundamental Principles of Arbitration]. Вестник Высшего арбитражного суда РФ [Herald of Supreme Arbitrazh Court of RF]. 4: 87-94.

Kovalenko, A.G., Mohova A.A., \& P.M. Filippova. (2014). Гражданский прочесс [Civil procedure]. Moscow.

Olshanskaya, L.V. (2014). 'История возникновения и развития коммерческих судов в России' [History of Emergence and Development of Commercial Courts in Russia]. Известия Московского государственного технического университета МАМИ [News of Moscow State Technical University MAMI]. 1(19): 96-102.

${ }^{53}$ The rules of the permanently functioning arbitral institution may provide the possibility of reducing the arbitrator's fees in cases of improper execution of his duties. 
Yarkov, V.V. (2002). 'Мировое соглашение в конкурсном производстве' [Settlementin Bankruptcy Proceedings]. Юopucm [Lawyer] 11:35-45.

YarkovV.V. (ed.) (2007). Арбитражный процесс [Arbitrazh procedure]. Moscow.

Yarkov,V.V. (ed.) (2014). Арбитражныйпроцесс [Arbitrazh procedure]. Moscow.

Yarkov, V.V. (2017). 'Признание и приведение в исполнение решений международного арбитража' [Recognition and execution of international arbitral awards] in Skvortsov O.Y. (ed.) (2017; forthcoming). Межсународный коммерческий арбитраж [International Commercial Arbitration]. Moscow. 
